
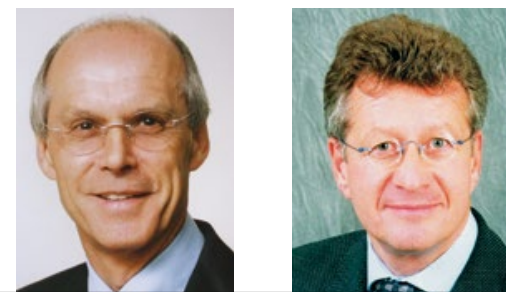

Dr. med. P. Stiefelhagen

\title{
Epstein-Barr-Virus
}

\section{Kann Mononukleose ein zweites Mal ausbrechen?}

? Dr. R. T.: Auf einem Fachvortrag zu Herpesviren wurde vor Kurzem behauptet, dass nach einer durchgemachten Mononukleose eine Reaktivierung nicht möglich sei. Ich hatte aber in Erinnerung, dass das durchaus vorkommen kann - ähnlich wie der Herpes Zoster nach einer früheren Varizella-Zoster-Virus-Infektion. Wie ist denn der Stand, und wie sichert man ggf. eine solche Reaktivierung?

MMW-Experte Stiefelhagen: Das Epstein-Barr-Virus (EBV) gehört zur Gruppe der Herpesviren. Nach einer durchgemachten Infektion bleibt das Virus - wie auch die anderen Herpeserreger - ein Leben lang im Körper, nämlich in den B-Lymphozyten. Es kann deshalb grundsätzlich zu einer Reaktivierung kommen, wobei meist aber nur leichte, unspezifische Symptome auftreten. Der genaue Auslöser lässt sich meist nicht identifizieren. Man muss in der Regel eine Schwächung des Immunsystems annehmen. Eine Reaktivierung lässt sich durch den erneuten Nachweis von Antikörpern vom IgM-Typ bestätigen. IgG-Antikörper sprechen nur für eine $\mathrm{zu}$ einem früheren Zeitpunkt durchgemachte Infektion. frühen Kindesalter und verlaufen asymptomatisch. EBV-Infektionen im

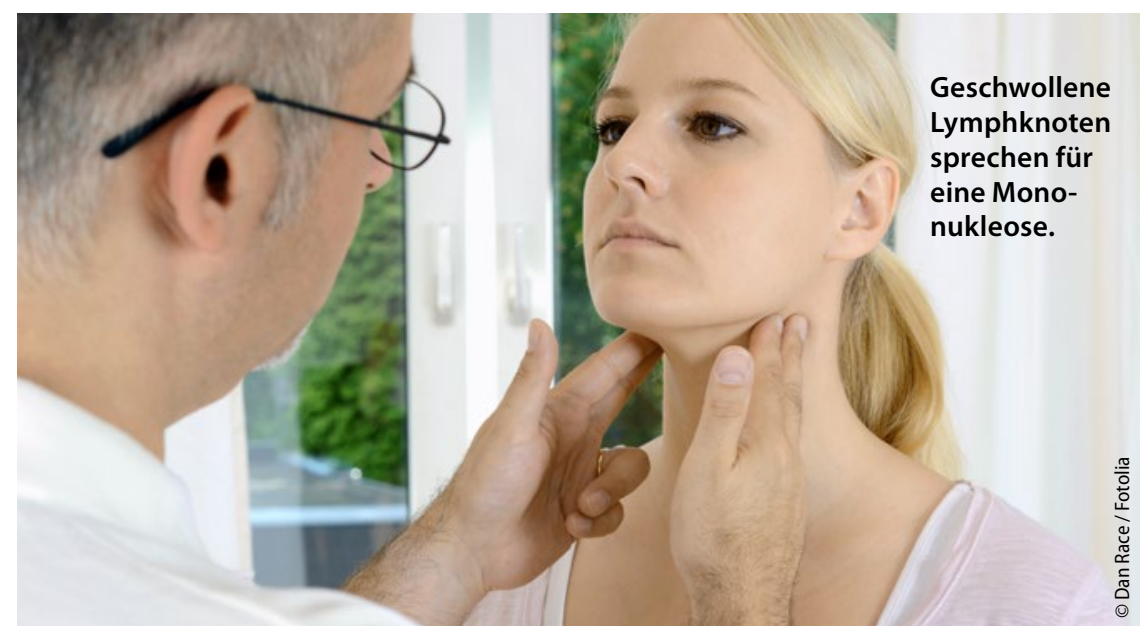

jungen Erwachsenenalter gehen mit einem fieberhaften Syndrom mit Lymphknotenschwellungen und Pharyngitis einher. Während die eigentliche Infektionskrankheit innerhalb weniger Wochen abgeklungen ist, kann es in einzelnen Fällen zu einer Überreaktion des Immunsystems mit anhaltender Schwäche und Müdigkeit bis zu einem Jahr kommen. In der Regel besteht eine lebenslange Immunität.

Wie bei allen Herpesviren sind aber aufgrund der lebenslangen Persistenz des Virus Reaktivierungen möglich. Diese sind an eine Schwächung des Immunsystems gebunden. Über die Häufigkeit einer derartigen Reaktivierung und die genauen Bedingungen, unter denen sie stattfindet, ist wenig bekannt. Die Erkrankung im Rahmen einer Re- aktivierung verläuft in der Regel leichter als nach der Erstinfektion. Bei iatrogener Immunsuppression nach Organtransplantation kann es allerdings zu B- und T-Zelllymphomen, Hodgkin-Lymphomen und Nasopharynxkarzinomen kommen, die wahrscheinlich ebenfalls mit einer Reaktivierung der EBV-Infektion assoziiert sind.

Die Sicherung einer Reaktivierung ist schwierig, da ältere serologische Befunde häufig nicht vorliegen. Sofern doch, so spricht ein positives VCA-IgG und EBNA-1-IgG und ein negatives VCA$\operatorname{IgM}$ in einem vor der Infektion abgenommenen Serum für eine alte Infektion, während bei der Reaktivierung VCA-IgM wieder positiv sein kann. Im Zweifelsfall könnte man die Reaktivierung mittels PCR sichern. 